EDITORIAL

\section{Could the Difference Between Normal and Malignant Stem Cells Eradicate Cancer?}

Normal stem cells provide a reserve for the renewal of tissues. This system, recognized a half of century ago, explained the hierarchy of descending cell populations ("generation-age hypothesis"1 and initiated a revolution in biomedical sciences. However, all aspects of stem cell "nature" are not yet revealed; even the hierarchy concept has been questioned, and no one has yet adequately defined this elusive "stem cell." One concept (the "chiaroscuro" model) supposes that a stem cell is a metastable functional entity that varies between a committed progenitor and a stem cell form. ${ }^{2}$

Regardless of how we define these fundamental phenomena, stem cell research has prompted, in the second decade of $21^{\text {st }}$ century, a real medical revolution: cellular therapy. Five decades after the paradigm of hematopoietic stem cells was established, the stem cell concept emerged in oncology, where the observed primitive cells were called "cancer initiating cells" or "cancer stem cells." Although the stem cell concept identifies these "cancer-initiating cells" as the main target of anti-cancer therapies, there is still debate about the process. ${ }^{3}$

At the same time, stem cell research indicates that both normal and cancer stem cells have much in common. Both have the anaerobic metabolism of a "primitive" cell phenotype $^{4}$ that was, so far, typically associated with cancer cells. In addition, normal and cancer stem cells exhibit many common features related to this primitive cell phenotype, including membrane antigens or markers, expression of transcription factors and activation of signals for cell quiescence/self-renewal.
The main challenge now is to identify differences between normal and cancer cells that will allow selective eradication of cancer stem cells without compromising normal tissue stem cell potential. ${ }^{5}$ Some recent studies point to dissimilarities that could be of capital importance, such as a difference in the PI-3 kinase pathway. ${ }^{6}$

In line with the practice of following particular hot topics, this issue of Scripta Medica contains a short segment in the Questions \& Answers.7 From a review paper entitled "Complexity of cancer stem cells," the characterization of cancer stem cells is presented. ${ }^{8}$

\section{References}

1. Rosendaal M, Hodgson GS, Bradley TR. Organization of haemopoietic stem cells: The generation-age hypothesis. Cell Tissue Kinet 1979;12.1:17.

2. Quesenberry PJ, Colvin GA, Lambert JF. The chiaroscuro stem cell: a unified stem cell theory. Blood 2002; 100.13: 4266.

3. Hanahan D, Weinberg RA. Hallmarks of cancer: the next generation. Cell 2011; 144.5: 646.

4. Ivanovic Z. Respect anaerobic nature of stem cells to exploit their potential in regenerative medicine; Regen Med 8(6) DOI:10.2217/RME.13.65 (2013).

5. Karsten U, Goletz S. What makes cancer stem cell markers different? SpringerPlus 2013; 2.1:301

6. Yilmaz OH, Morrison SJ. The PI-3kinase pathway in hematopoietic stem cells and leukemia-initiating cells: a mechanistic difference between normal and cancer stem cells. Blood Cells Mol Dis. 2008; 41.1:73.

7. Popovoć-Pejičić S. Questions and Answers. Scr Med 2013;44:101-4.

8. Sugihara E, Saya H. Complexity of cancer stem cells. Int J Cancer 2013;132:1249-59.

\section{Zoran Ivanovic}

Aquitaine-Limousin Branch of French Blood Institute \& UMR5164 CNRS/Segalen University, Bordeaux, France

\section{Correspondence}

Zoran Ivanovic $M D, P h D, H D R$

Etablissement François du Sang Aquitaine Limousin,

Place Amélie Raba Léon CS 21010

33075 Bordeaux, France 